\title{
The Influence of Different Seeding Space and Organic Fertilization Level upon Production and Mass of 1000 Seeds, Recorded in Some Hemp Varieties
}

\author{
Adriana Iuliana DAN ${ }^{1}$, Marcel M. DUDA ${ }^{1}$, Cristina MOLDOVAN ${ }^{1}$, Teodora FLORIAN ${ }^{1}$ \\ ${ }^{1}$ University of Agricultural Sciences and Veterinary Medicine, 3-5 Mănăştur Street, 400372 Cluj- \\ Napoca, Romania; \\ * corresponding author: daniuliana_adriana@yahoo.com
}

Bulletin USAMV series Agriculture 72(1)/2015

Print ISSN 1843-5246; Electronic ISSN 1843-5386

DOI 10.15835/buasvmcn-agr: 11159

\begin{abstract}
Hemp (Cannabis sativa L.) was used for textile and cordage more than 4000 years. The cultivation of industrial hemp declined in the 19th century but it remains one of the oldest crops in history. Despite of the decline, nowadays interest for this crop has recently been renewed within various European countries (Roman et al., 2012). The aim of the research is to observe the evolution of production values and physical parameters (MMB- grain) under the influence of different seeding space and organic fertilization level recorded in some hemp varieties approved in Romania, with a low level of THC.
\end{abstract}

Keywords: fertilization, hemp, MMB-grain, production, seeding space.

\section{INTRODUCTION}

Originate from China, hemp is cultivated over 2000 years, for paper, canvases, ropes, and also food production.

In our country, hemp is one of the oldest cultivated plants, the main use was for clothing production.

Until '89, Romania, owned first place in Europe and fourth place world wide for cultivated areas with hemp, over 45.000 hectares.

Today,unfortunelly, hemp acreage declined dramatically, the major factors who contributed were disappearance of smelters, negative association/confusion with marijuana („Cannabis indica"), current legislation, which does not allow to grown hemp, without an authorization.

Nowadays, it is aimed a relaunch for hemp culture, the main purpose is for obtaining the hempseed.These have a a rich content in protein, unsaturated fatty acids (Omega 6 and Omega 3), in ratio $3: 1$, the ideal ratio for human consumption recommended and confirmed by numerous medical research.

The first therapeutic use of the hemp plant, documented in Arabic literature, dates back to the $8^{\text {th }}$ or $9^{\text {th }}$ century. The most commonly used part of the plant at that time, were the seeds, and, to a smaller extent, the leaves.

Today we know that the essential fatty acids act through various action mechanisms such as the metabolites and the messengers. They play crucial roles in the metabolic traffic due to their effect on the nuclear receptors. These fatty acids can directly affect the nuclear receptors, by activating or repressing a series of metabolic pathways that are necessary for the correct defensive response of a cell. They also allow an organism to form the 
eicosanoid molecules involved in the reproductive functions, inflammation processes, fever and pain production. The essential fatty acids have an impact on the traumas and diseases, in the formation of blood clots, regulation of blood pressure, secretion of gastric acid and on many other processes that are important for human health.

\section{MATERIALS AND METHODS}

Our study was based on a trifactorial experience:

A Factor - hemp varieties

$\mathrm{a}_{1}$ - Dacia Secuieni (monoecious hemp), from SCDA

Secuieni, Romania

$\mathrm{a}_{2}$ - Denise (monoecious hemp), from SCDA

Secuieni, Romania

$\mathrm{a}_{3}$ - Zenit (monoecious hemp), from SCDA Secuieni,

Romania

B Factor - fertilization

$\mathrm{b}_{1}$ - unfertilized

$b_{2}$ - foliar fertilization with Fertitel (60ml/200sqm)

$\mathrm{b}_{3}$ - foliar fertilization with Biostar (40ml/200sqm)

C Factor - plants density

$\mathrm{c}_{1}-333.000 \mathrm{pl} / \mathrm{ha}(30 \mathrm{~cm} \times 10 \mathrm{~cm})$

$\mathrm{c}_{2}-200.000 \mathrm{pl} / \mathrm{ha}(50 \mathrm{~cm} \times 10 \mathrm{~cm})$

$\mathrm{c}_{3}-143.000 \mathrm{pl} / \mathrm{ha}(70 \mathrm{~cm} \times 10 \mathrm{~cm})$

The hemp varieties studied are authorized, according to the Official Catalogue of varieties of crop plants in Romania, edition 2012 and comes from Secuieni (Roman, Romania), Agricultural Research and Development Station and includes the following morphological characteristics:

Dacia Secuieni, it was registreted in 2012, have high stem, which can reach over 4 meters in seed culture. The vegetation period is between 120-130 days.

Can achieved a stem production between 8,5 $-11.8 \mathrm{t} / \mathrm{ha}$, with a fiber content of good quality and the seed production can exceed 1000 kilograms.

The hemp varitety, Denise, is a monoecoius plant and was recorded in 1999.Stem is high, between 2,5 - 3 meters and the growing season is 120-130 days. The stems production are between 11-12 t/ha and seed production is estimated to 900 kilograms.

Zenit was homologated in 2000 , the vegetation period is between 120-130 days in seed culture and 90-110 days for fibre culture. The seed production capacity is estimated to $1200 \mathrm{kilos} / \mathrm{ha}$ and strains production, $8-9$ /ha.

The autumn-plowing was caried at $20-25 \mathrm{~cm}$, and smoothed finely with a big disk harrow and with small disk. The seeding of monoecious hemp took place on 27.04.2012.

It is known from the literature that the row spacing for hempseed cultivar is $60-70 \mathrm{~cm}$ and 10 $12 \mathrm{~cm}$ between plants providing seed density 2025 seeds $/ \mathrm{m}^{2}$ (Şandru et all,1996). Tabãrã (2005) obtained the best results on the distance of 37,5 $\mathrm{cm}$.

The spacing between rows was $70 \mathrm{~cm}, 50 \mathrm{~cm}$ and $30 \mathrm{~cm}$ and the distance between plants on row was $10 \mathrm{~cm}$.

During the growing season was applied an extract from Tagettes sp. to control the invasion of fleas, which had a repellent effect against fleas.

Also, in July, the culture was foliar fertilized with two biological fertilizers, Biostar and Fertitel.

The harvest took place in 07.09.2012 with car combine for experimental fields Wintersteiger.

The experimental technique for bi-factorial experiences was used. The two factor variance analysis was used for calculations. Interpretation of the significance of the differences was made using the " $\mathrm{t}$ " test and Duncan test.

\section{RESULTS AND DISCUSIONS}

The application of fertilizers on Denise variety has increase the mass of 1000 grains value.

The control unfertilized recorded $15.16 \mathrm{~g}$, results obtained are higher with $1.42 \mathrm{~g}$ (Fertitel) and $1.89 \mathrm{~g}$ (Biostar). The fertilization with Biostar has decreased the mass of 1000 grains for Dacia Secuieni and Zenit varieties (table 1).

Compared to the control (density $143.000 \mathrm{pl}$ / sqm) the mass of 1000 grains is directly influence for Denise variety, the difference by the control are significantly distinct for $333.000 \mathrm{pl} / \mathrm{sqm}$ denisty, the differences recorded being $1.17 \%$ and are presented in table 2 .

The highest hemp seed production was recorded to Zenit variety, at $333.000 \mathrm{pl} / \mathrm{sqm}$ density and the value obtained was $603.27 \mathrm{~kg} / \mathrm{ha}$.

The hemp variety Denise has recorded the lowest seed production $(253.49 \mathrm{~kg} / \mathrm{ha})$, the differences obtained compared to control (Zenit variety) were significantly negative, the differences are related in table 3. 
Regarding the relation between mass of 1000 grains and hemp seed production, it can be observe that at Denise and Zenit varieties the relation mentioned is directly proportional, a high value of mass of 1000 grains is correlated to high hemp seed production. As an exception, the relation between these two production elements in case of Dacia Secuieni variety, a high value of mass of 1000 grains does not lead to a high seed production. The explication ca be the number of seeds on plant for Dacia Secuieni variety compared with other 2 varieties studied (figure 1).

\section{CONCLUSIONS}

The crop quality and quantity depends on plants density, the seed productions increase with the increase of the plants density. The absence

Tab. 1. Mass of 1000 grains obtained for the varieties tested in different fertilization conditions

\begin{tabular}{|c|c|c|c|c|c|c|}
\hline Variety & Fertillization & $\begin{array}{c}\text { MMB } \\
\text { (mass of } 1000 \\
\text { grains) }\end{array}$ & $\begin{array}{c}\% \text { by } \\
\text { control }\end{array}$ & Difference & Significance & $\begin{array}{c}\text { Duncan } \\
\text { Test }\end{array}$ \\
\hline \multirow{3}{*}{ Dacia Secuieni } & unfertilized & 16,47 & 100,0 & 0,00 & Mt. & B \\
\hline & Fertitel & 16,64 & 101,0 & 0,17 & - & B \\
\hline & Biostar & 16,27 & 98,8 & $-0,20$ & - & B \\
\hline \multirow{3}{*}{ Denise } & unfertilized & 15,16 & 100,0 & 0,00 & Mt. & A \\
\hline & Fertitel & 16,59 & 109,4 & 1,42 & ** & B \\
\hline & Biostar & 17,06 & 112,5 & 1,89 & $* * *$ & B \\
\hline \multirow{3}{*}{ Zenit } & unfertilized & 16,72 & 100,0 & 0,00 & Mt. & $B$ \\
\hline & Fertitel & 16,19 & 96,9 & $-0,52$ & - & B \\
\hline & Biostar & 16,34 & 97,7 & $-0,38$ & - & $B$ \\
\hline \multicolumn{2}{|l|}{ DL (LSD) (p 5\%) } & & & 0,81 & & \multirow{3}{*}{$S D=0,86$} \\
\hline \multirow{2}{*}{\multicolumn{2}{|c|}{ DL (p 1\%) }} & & & 1,14 & & \\
\hline & & & & 1,67 & & \\
\hline
\end{tabular}

Tab. 2. Mass of 1000 grains obtained for the varieties tested in different fertilization seeding space

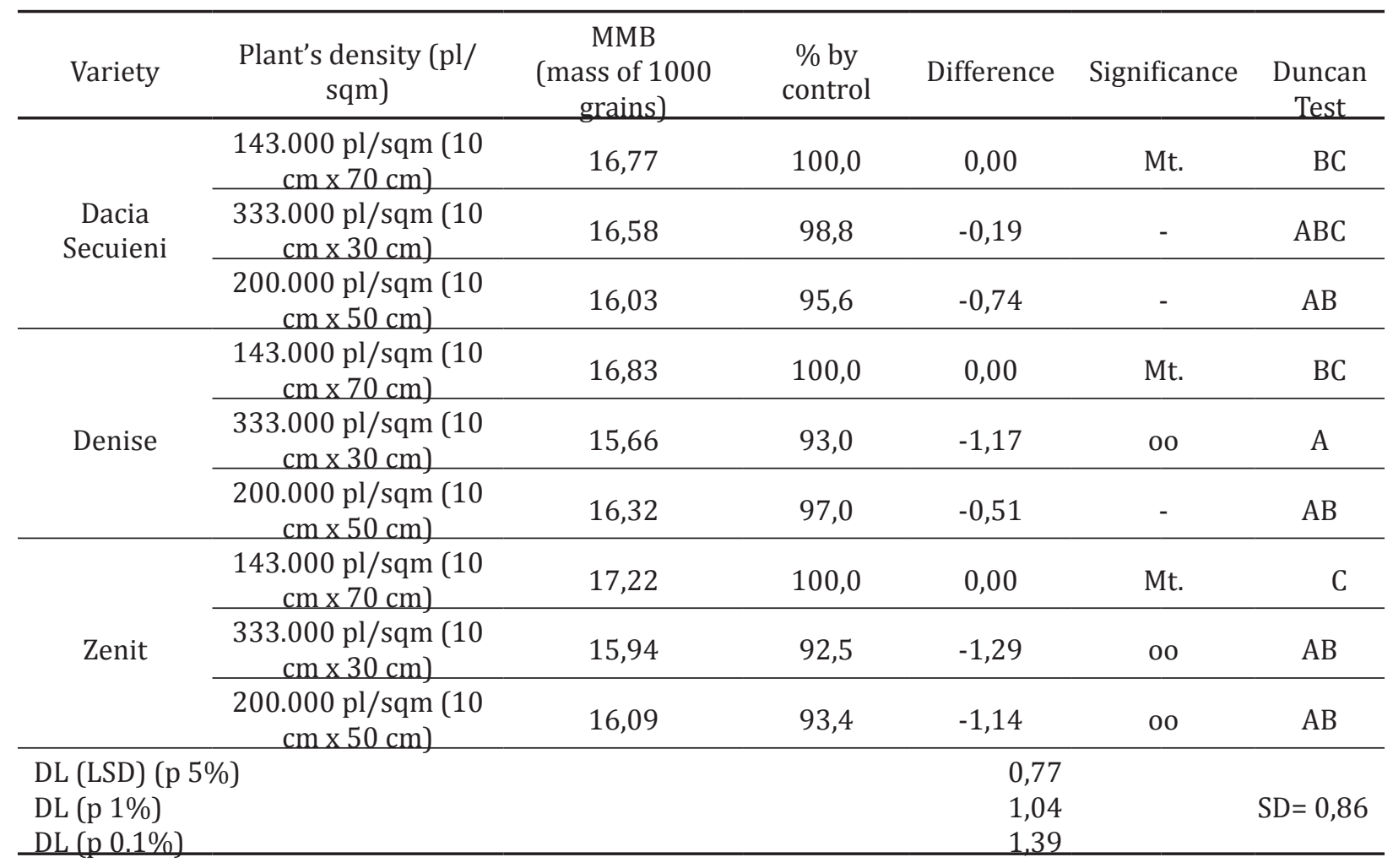


Tab. 3. Production obtained for the varieties tested in different fertilization seeding space

\begin{tabular}{|c|c|c|c|c|c|c|}
\hline Variety & Fertillization & $\begin{array}{c}\text { Production } \\
\mathrm{kg} / \mathrm{ha}\end{array}$ & $\begin{array}{c}\% \text { by } \\
\text { control }\end{array}$ & Difference & Significance & $\begin{array}{c}\text { Duncan } \\
\text { Test }\end{array}$ \\
\hline \multirow{3}{*}{$\begin{array}{l}\text { Dacia } \\
\text { Secuieni }\end{array}$} & $\begin{array}{c}143.000 \mathrm{pl} / \mathrm{ha}(10 \mathrm{~cm} \mathrm{x} \\
70 \mathrm{~cm})\end{array}$ & 382,00 & 100,0 & 0,00 & Mt. & $\mathrm{ABC}$ \\
\hline & $\begin{array}{c}333.000 \mathrm{pl} / \mathrm{ha}(10 \mathrm{~cm} \mathrm{x} \\
30 \mathrm{~cm})\end{array}$ & 454,00 & 118,8 & 72,00 & - & $\mathrm{BC}$ \\
\hline & $\begin{array}{c}200.000 \mathrm{pl} / \mathrm{sqm}(10 \mathrm{~cm} \mathrm{x} \\
50 \mathrm{~cm})\end{array}$ & 352,90 & 92,4 & $-29,10$ & - & $\mathrm{AB}$ \\
\hline \multirow{3}{*}{ Denise } & $\begin{array}{c}143.000 \mathrm{pl} / \mathrm{sqm}(10 \mathrm{~cm} \mathrm{x} \\
70 \mathrm{~cm})\end{array}$ & 243,49 & 100,0 & 0,00 & Mt. & A \\
\hline & $\begin{array}{c}333.000 \mathrm{pl} / \mathrm{sqm}(10 \mathrm{~cm} \mathrm{x} \\
30 \mathrm{~cm})\end{array}$ & 372,00 & 152,8 & 128,51 & - & $\mathrm{ABC}$ \\
\hline & $\begin{array}{c}200.000 \mathrm{pl} / \mathrm{sqm}(10 \mathrm{~cm} \mathrm{x} \\
50 \mathrm{~cm})\end{array}$ & 346,00 & 142,1 & 102,51 & - & $\mathrm{AB}$ \\
\hline \multirow{3}{*}{ Zenit } & $\begin{array}{c}143.000 \mathrm{pl} / \mathrm{sqm}(10 \mathrm{~cm} \mathrm{x} \\
70 \mathrm{~cm})\end{array}$ & 448,80 & 100,0 & 0,00 & Mt. & $\mathrm{BC}$ \\
\hline & $\begin{array}{c}333.000 \mathrm{pl} / \mathrm{sqm}(10 \mathrm{~cm} \mathrm{x} \\
30 \mathrm{~cm})\end{array}$ & 603,27 & 134,4 & 154,47 & $*$ & $\mathrm{D}$ \\
\hline & $\begin{array}{c}200.000 \mathrm{pl} / \mathrm{sqm}(10 \mathrm{~cm} \mathrm{x} \\
50 \mathrm{~cm})\end{array}$ & 504,00 & 112,3 & 55,20 & - & CD \\
\hline \multirow{2}{*}{\multicolumn{2}{|c|}{$\begin{array}{l}\text { DL (LSD) (p 5\%) } \\
\text { DL (p 1\%) }\end{array}$}} & & & 135,85 & & \multirow[b]{2}{*}{$S D=135,72$} \\
\hline & & & & $\begin{array}{l}190,69 \\
\end{array}$ & & \\
\hline
\end{tabular}

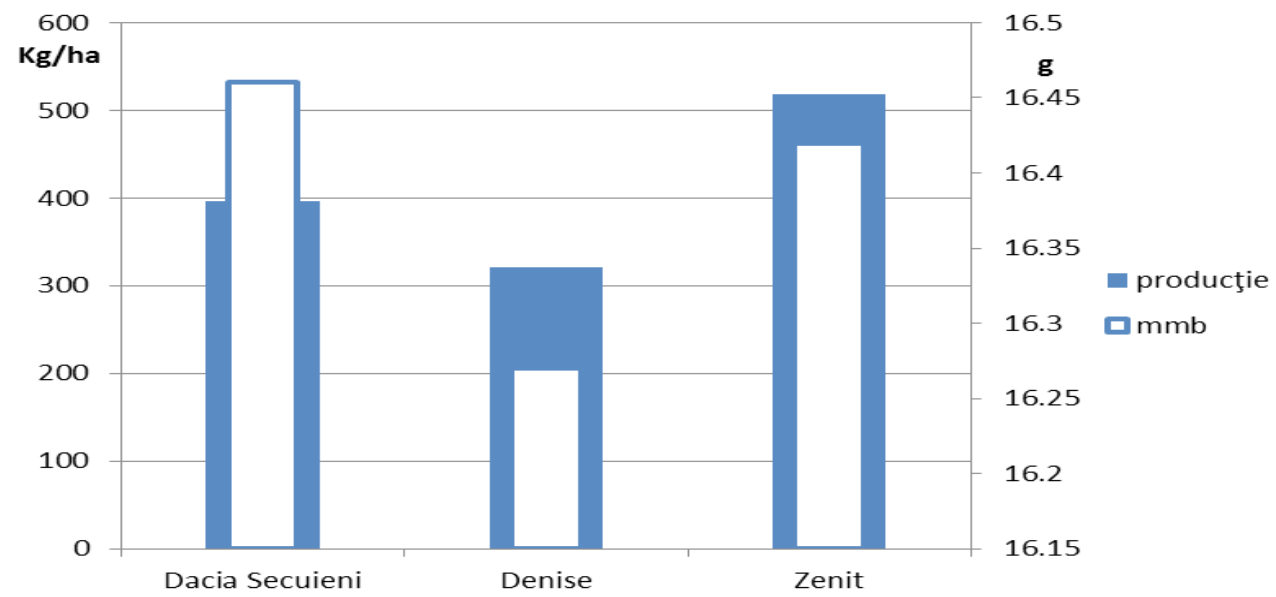

Fig.1. The relation between mass of 1000 grains and hemp seed production recorded in 2012

of precipitation recorded in July, August caused decreases in seed production.

The foliar fertilization with Biostar has decreased the mass of 1000 grains for Dacia Secuieni and Zenit hemp varieties.

Denise variety has responded favorably to fertilization, the mass of 1000 grains has increased higher with $1.42 \mathrm{~g}$ (Fertitel) and $1.89 \mathrm{~g}$ (Biostar) compared to the control.

The highest hemp seed production was recorded to Zenit variety, at $333.000 \mathrm{pl} / \mathrm{sqm}$ density and the value obtained was $603.27 \mathrm{~kg} / \mathrm{ha}$.

\section{REFERENCES}

1. Callaway JC (2004). Hempseed as a nutritional resource: An overview. Euphytica 140: 65-72.

2. Muntean LS, Cernea S, Morar G,. Duda MM, Vârban DI, Muntean S (201). Fitotehnie. Ed. a II-a, Risoprint, ClujNapoca, ISBN 978-973-53-0506-2.

3. Roman GV, Morar G, Robu T, Ștefan M, Tabără V, Axinte M, Borcean I Cernea S (2012). Fitotehnie. Vol. 2, Plante tehnice, medicinale şi aromatice. Ed. Universitară, Bucureşti. ISBN 978-606-591-567-1:466. 